\title{
Faith-based healing and African traditional medicine in Zimbabwe: A postcolonial perspective
}

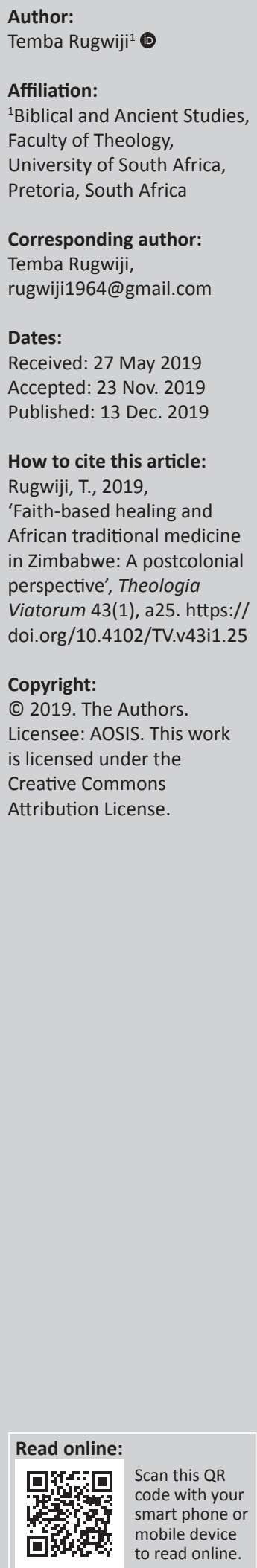

The missionary church in Africa had its own challenges regarding the missionary enterprise itself and the local African communities to which the Gospel was preached. Various opinions on the missionary enterprise in Africa have been advanced. The main argument raised by most scholars is primarily premised on the negative impact of colonialism, citing the vilification of African cultural practices and discouraging converts to the Christian faith from using African traditional medicine (ATM). The latter view constitutes the main problem that the present discourse intends to grapple with. The present study will engage the existing scholarly literature on the argument that the missionary churches did not familiarise themselves with cultural practices of the local indigenous African peoples prior to convincing them about switching to God who is presented in the Hebrew Bible (HB). It has been established that according to the HB and Christian teachings, the use of ATM is an abomination. In this study, faith-based healing $(\mathrm{FBH})$ and other methods of healing in Africa in general and Zimbabwe in particular are also discussed. This study utilises a postcolonial approach in an attempt to explain ancient Israelite cultural practices and FBH in the modern post-biblical context. The purpose of this study is twofold: (1) to explain for the readership the critical role played by the missionary churches among African communities and (2) to present the research findings for further research on the authenticity (or myth) of FBH claims.

Keywords: the missionary church; Pentecostal movements; faith-based healing; African traditional religion; ATM.

\section{Introduction}

Numerous contributions have been published to date about the impact of colonialism on Africa and African culture. However, very few (or none) have succeeded in interrogating the biblical view of healing from a postcolonial perspective, with a particular focus on promoting African traditional medicine (ATM) in Zimbabwe. With reference to the Old Testament (OT), it is depicted that the colonists would deny the people whose land they have invaded the right to maintain their cultures and their traditional belief systems (Stephanson 1995:6-7). Thus, Kwok (1995) opined that:

The condemnation of cultures, religions, and peoples in Canaan can be seen as a forerunner of discrimination against peoples who do not share the beliefs of Jews or Christians. The Canaanites were portrayed as worshipping idols, as promiscuous, and as having lower moral standards. (p. 108)

The present study attempts to demonstrate that this trajectory of mortifying cultural practices of people of the invaded territory has also been exported through the missionary church to our contemporary world, particularly the African continent. Hence, Ngwabi Bhebe (1979:28) remarked that ' $[t]$ he LMS missionaries had by the 1880's come to the conclusion that the Ndebele political system must be overthrown to pave the way for Christianity'. The missionaries ${ }^{1}$ who were believed to be preachers of the Gospel of Christ to the 'unborn world' also assimilated biblical teachings, which disregarded cultures and traditional practices of the indigenous people ${ }^{2}$ (cf. Mofokeng 1988:34; Mudimbe 1977:44; West 1997:322-342). As Rugwiji (2013:59) remarked, '[a] known culture or tradition of a people remains their identity marker' (see also Ratheiser 2007:460). This is one of the arguments raised by virtually the majority of Africans in general, and African scholars in particular, that the missionary church was part of the superseding agenda of

1.Most missionaries to Africa in general and Zimbabwe in particular came from Europe and the United States of America. See, for example, Makunike (1998) and Mofokeng (1988:34).

2.Although the missionary hermeneutical perspective cannot be identified categorically (because they came at different times and with different approach), it is well documented that the presence of missionaries in Rhodesia (Zimbabwe was previously known as 'Rhodesia') was a mixed bag. While others were devoted to purely interpreting and preaching the Gospel, numerous others had some political ambitions. 
colonisation because the missionaries are believed to have brought the concept of God to Africa (Cox 2014). Thus, Mishra and Hodge (1994:288) have argued that '[c]olonialism was accomplished through Christian mission in Africa'. The above view supports Rugwiji's (2008:100) argument that to conquer a people effectively, subjugation is done through the use of ideas. Thus, a racial protest has continued among Africans that when missionaries came to sub-Saharan Africa they subjugated black people under white administration because 'white' is regarded as civilised, good, beautiful, intelligent and rational (Holderness 1985:5).

The culture of the African people, their rituals and traditional ceremonies were perverse. Cultural names of local people who were convinced to join the church were changed because local Shona names were considered to be carrying curse connotations. However, this study does not suggest the renaming of all colonial names in Zimbabwe. But, one would consider that '[f]or black people, the past and its ineffaceable and haunting marks of dehumanisation are not something with which they can easily reconcile' (Nyambi \& Mangena 2016:6). African traditional medicine and local herbs to cure illnesses and other health complications were discouraged. Even the modern generation of Christians has accepted the church's condemnation that ATM is satanic. This is why African ways of healing ailments using local concoctions and traditional herbs are almost extinct. The modern church has firmly adopted and adapted to the missionary church's teachings and ideology against African cultural belief systems. Four fundamental themes will be explored in this discourse: (1) faith, ritual and healing in the Bible, (2) the missionary church and African cultures, (3) ATM and the position of the Church and (4) Pentecostalism and faithbased healing $(\mathrm{FBH})$ in Zimbabwe.

The present study utilises a postcolonial approach that examines the era after colonialism (Castle 2001:508; Hall 1996:260). In adopting the above approach, the project is organised into two main objectives. Firstly, the study attempts to illustrate for the readership in general that experiences of oppression, injustice and discrimination against Africans during the colonial era have had a negative impact on African communal life and cultural practices. Having said that, the church $^{3}$ and its contribution in subjugating Africans cannot be exonerated entirely. Thus, Banana (1991:35) remarked that 'Africans were to a large extent, not regarded as humans; their status is analogous to or lesser still in importance to that of a pet like a dog'. Secondly, scholarship stands to benefit from this contribution because there are significant variances envisaged in this particular discourse which have not been explored implicitly elsewhere. These variances include, for instance, a discussion that a conventional medical practitioner should recommend some patients with health complications to seek the help of a traditional healer and/or solicit ATM in spite of the argument that ATMs 'are not laboratory tested' (Ndlovu 2016:50). Nevertheless, as Bodibe and Sodi
(1997, cited in Ndlovu 2016:20) observed, '[s]everal studies have maintained that people would rather consult a traditional healer than any other care or treatment option'.

\section{Problem statement}

The present discussion has identified three main problems that have motivated an informed dialogue with the biblical text, scholarly literature and material on culture and traditional medicines among Africans in Zimbabwe.

Firstly, postcolonial literature on the role of the missionary church in Africa has not explored in detail the critical functions played by the sacred institutions towards the provision of social services, such as food security, education and healthcare to local communities which the present study does. The readership can be guaranteed of a balanced debate on the missionary enterprise and its crucial role in Africa.

Secondly, the study attempts to sensitise the readership among faith-based organisations (FBOs) and culturally entrenched communities to foster a breakthrough towards acceptability of modern conventional precautionary measures against viruses and diseases which can easily overtake congregants, especially the young ones. Recommending hospital treatment is not asking too much. In the same vein, conventional medical practitioners should recommend patients with health complications to a traditional healer or for the use of ATM.

Thirdly, it has been noted that both past and most recent postcolonial studies on the colonisation of Africa and African peoples have tended to be reactionary and revolutionary in character. However, the present study attempts to create a platform for a conjectural dialogue towards appreciation for a new world order that necessitates an appreciation of cultural variances.

\section{Methodology}

As discussed previously, this study adopted a postcolonial approach (postcolonial theory ${ }^{4}$ ). Snyman (2002:63-88) describes 'postcolonial' as a 'condition where serious questions are asked about the continuing effect of the former colonial and apartheid ideological structures'. In addition to Snyman's position on postcoloniality, Sugirtharajah (2002) explains postcolonialism as follows:

$[T]$ o term the former colonised countries of Asia and Africa, the Caribbean and the Pacific as postcolonial as they become selfgoverning states. Recently there has been a development and shift in the meaning of the term. It has moved from a fairly common understanding as a linear chronological sequence to a much more catholic and more diverse sense, as an index of historical and cultural changes. Despite the formal withdrawal of European nations, the term 'postcolonial' is thought to be an appropriate one because of the persistence of newer forms of economic and cultural colonialism which keep a number of

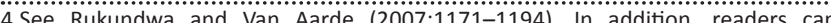
familiarise themselves with the following representative examples: Sugirthaja (2002), Castle (2001), $Y$ (2002), Castle (2001), Young (2001), Ashcroft, Griffiths and Tiffin (2000), Bhabha (1994), Said (1993), Frankenberg and Mani (1993), Fanon (1991) and Spivak (1988), among others. 
newly independent states in check and constrain their freedom. The term as it is now used, whether referring to textual practices or psychological conditions, or historical processes, depends on who uses it and what purpose it serves. (p. 2)

In this article, both precolonial and colonial literature about African cultures (including African indigenous knowledge systems ${ }^{5}$ ), missionary churches and how they established health and learning institutions are interrogated in dialogue with postcolonial findings that emerged as an inquiry into the legitimacy of place, space and identity of African peoples and their cultures. In addition to secondary sources used in developing this argument, themes drawn from biblical narratives will also be explored. Scholars who have employed biblical passages as their bases for engagement as well as postcoloniality also comprise an essential component of the data pool for the present discourse.

\section{Faith, ritual and healing in the Bible}

During ancient biblical times (both the OT and New Testament [NT]), like in a modern post-biblical world, health was an important subject. This investigation on health commences by tracing themes of health and healing in the OT. This approach is an attempt to demonstrate that in the Hebrew Bible (which is regarded as historical by both Jews and modern Christians), health matters were as critical as they are among modern post-biblical societies. In addition, the inclusion of OT narratives about healing in a postcolonial discourse is in order, not only because of its relevance but also because of its consistency with the question of health from the standpoint of the Bible. Hence, commencing with the Bible, which both the Jews and Christians make reference to frequently, informs the present study from a postcolonial perspective.

In the book of Exodus, Yahweh declares himself as a healer where he says, 'I, the Lord, am your healer' (Ex 15:26b). One would also want to appreciate the legitimacy of Hasel's (1983:197) affirmation when he claims that the Lord of the covenant is perceived as the 'healer' in the prevention of the diseases which afflicted the Egyptians. Hasel (1983) further revealed that obedience to the Lord would prevent Yahweh from bringing diseases upon the covenant people (Ex 15:26a). The practice of ritual cleansing or healing ritual was also performed during OT times. A few examples are noteworthy: in Exodus 4:24, we read that Yahweh intended to kill Moses. The biblical text does not present the readers with some clarity as to why Yahweh wanted to kill the agent whom he had assigned to bring liberation of the Israelites from Egyptian bondage. It is conceivable that Yahweh intended to kill Moses because he had disobeyed Yahweh by not circumcising his son. Nevertheless, it appears Moses became very ill and it was his wife Zipporah who saved his life. Zipporah performed a ritual in which she 'took a sharp stone, and cut off the foreskin of her son, and cast it at his feet ...'

5.For African Indigenous Knowledge Systems (AlKSs), see, for example, Dondolo (2005:112) who opines that indigenous people practise and protect a total sum of $(2005: 112)$ who opines that indigenous people practise and protect a total sum of
knowledge and skills constitutive of their meaning, belief systems, livelihood constructions and expression that distinguish them from other groups.
(Ex 4:24-26; Allen 1996: 259-269). This circumcision ritual healed Moses. Leviticus 13 depicts leprosy as a dreadful disease. According to Leviticus, a person suffering from leprosy had to be kept away from the rest of the communities until such a time when the priest pronounced them clean. In Leviticus 14, we read of a ritual of cleansing (healing) lepers which is performed by a priest ( $\operatorname{Lv} 14: 3)$, in which 'two birds alive and clean, and cedar wood, and scarlet, and hyssop' ( $\mathrm{Lv}$ 14:4) would be brought to the priest. One of the birds is killed in an earthen vessel over running water ( $\mathrm{Lv} 14: 5)$. The ritual is concluded by sprinkling the blood of the killed bird on the leper ( $L v$ 14:6). The Prophet Elisha raised the son of a Shunammite woman from the dead. He laid:

$[U]$ pon the child, and put his mouth upon his mouth, and his eyes upon his eyes, and his hands upon his hands: and he stretched himself upon the child; and the flesh of the child waxed warm. (2 Ki 4:34)

Likewise, the Prophet Elisha orders Naaman, the leper, (2 Ki 5:1) to wash himself in the Jordan river seven times after which Naaman was healed of his leprosy (2 Ki 5:14). In the realisation that Yahweh is a healer, Moses cried to Yahweh to heal his leprous sister Miriam (Nm 12:13). In the song of Moses, Yahweh is personified as one who kills, wounds and heals and that 'neither is there any that can deliver out of my hand' (Dt 32:39), a ramification which we also find in Job 5:18. However, Job was cured from his disease and has enjoyed a long and happy life together with his family (Spronk 2004:989).

It is envisaged that dietary precautions were critical among the covenant people. Swindoll (1988:326) has furnished us with cases of pregnant women such as Samson's mother and Elizabeth who were subjected to special diets and home confinement to ensure a healthy full-term delivery (Jdg 13:4-5; Lk 1:24). Following the prevalence of drought and the barrenness in the land which consequently brought death among people, the Prophet Elisha performed a ritual of healing the:

[S]pring of the waters, and cast the salt in there, and said, 'Thus saith the Lord, I have healed these waters; there shall not be from thence any more death or barren land.' (2 Ki 2:21-22)

In the book of Second Chronicles, we read that Hezekiah prayed for the sick and Yahweh healed Israel (2 Chr 30:20). In 2 Chronicles 7:14, Yahweh's requirement as a condition for healing the land was humility, prayer, seeking Yahweh's face, and turning away from wickedness. Yahweh's mercies are also demonstrated by his ability to 'healeth the broken in heart, and bindeth up their wounds' (Ps 147:3). It is noted that trusting in the Lord will bring 'health to thy navel, and marrow to thy bones' (Pr 3:8). In the fourth servant song (Is 53:5), the audience is assured that 'with his stripes we are healed' (see also 1 Pt 2:24).

Although the position of the modern Church is that this particular song referred to Jesus Christ who was bruised and nailed to the Cross for the salvation of the human race, the majority of scholars hold the view that the servant was 
among the suffering Jews in captivity in Babylonia, during which time Jesus had not yet been born. Another important example of sickness and healing in the OT is King Hezekiah (Isaiah 38). According to Isaiah 38:1-6, Hezekiah's health was restored because of the intervention of the Prophet Isaiah and King Hezekiah's contribution through prayer. Thus, it reads:

In those days Hezekiah was sick unto death. And Isaiah the prophet the son of Amoz came unto him, and said unto him, 'Thus saith the Lord, "Set thine house in order: for thou shalt die, and not live"'. Then Hezekiah turned his face toward the wall, and prayed unto the Lord. Then came the word of the Lord to Isaiah, saying, 'Go, and say to Hezekiah, "Thus saith the Lord, the God of David thy father, I have heard thy prayer, I have seen thy tears: behold, I will add unto thy days fifteen years"'. (Is 38:1-6)

Jeremiah also complained to Yahweh about a continued state of suffering among the people, to which he added that, 'Is there no balm in Gilead; is there no physician there? Why then is not the health of the daughter of my people recovered?' (Jr 8:22). The Prophet Jeremiah, who was probably sick himself, cried to Yahweh: 'Heal me, O Lord, and I shall be healed; save me, and I shall be saved: for thou art my praise' (Jr 17:14). Added to that we read in Jeremiah 30:17 that Yahweh promised the exiles that he would 'restore health unto thee, and I will heal thee of thy wounds' In Psalms 6:2, David prays to Yahweh to 'Have mercy upon me, O Lord; for I am weak: O Lord, heal me; for my bones are vexed'. Apparently, God could also strike people's sickness, for example, the child that Bathsheba bore to David (see 2 Sm 19:37). When Zechariah says:

For I am going to raise up a shepherd over the land who will not care for the lost, or seek the young, or heal the injured, or feed the healthy, but will eat the meat of the choice sheep, tearing off their hoofs. (Zch 11:16)

He might have been referring to the post-exilic leadership among the Judeans who did not care for the welfare of communities.

The book of Malachi informs us of the healing that would prevail if the Judeans revered Yahweh. The following statement portrays someone who has been healed who now leaps with joy because they are released from the bondage of illness:

But for you who revere my name, the sun of righteousness will rise with healing in its wings. And you will go out and leap like calves released from the stall. (Ml 4:2)

The beginning of Psalm 41 speaks about the spiritual and physical solace in times of trouble that comes from serving others (especially Ps 41:4; Freeman \& Abrams 1999:3). Because of back pain someone complains that 'there is no health in my body' (Ps 38:7), while others 'have no struggles; their bodies are healthy and strong' (Ps 73:4). Yahweh is also perceived as one 'who pardons all your iniquities; who heals all your diseases' (Ps 103:3). Proverbs 2:13 echoes with the fear of the Lord and the shunning of evil 'will bring health to your body and nourishment to your bones'. In addition, is the teaching of Proverbs 12:18 that a person who is wise should promote and enhance life by using one's tongue to speak health. Isaiah 58:8 also gives hope to those who are sick when he says, 'Then your light will break forth like dawn; and your healing will quickly appear'. The book of Job is also illuminating in its revelation of Yahweh as the provider and sustainer of health and good life. Klopper (1992) expresses the same view explicitly in the following statement:

Those who lived in harmony with Yahweh's will enjoy his blessing of good health, prosperity and contentment. It was not a condition of being saved unto life hereafter. To die in good old age, an old man, and full of years (Job 42:17) was to have reached a point which Yahweh had measured and now completed. (p. 200)

The NT also depicts that health and healing of sicknesses were critical. Hence, Hasel (1983:191) remarks that healing, forgiveness and salvation are not (and cannot be) separated in Scripture. A few examples of healing in the NT will suffice. Jesus healed the leper by touching him (Mt 8:3); he touched the mother of Peter's wife who had fever (Mt 8:14-15); Jesus touched the eyes of two blind men, and they were healed (Mt 20:34). Sometimes Jesus would heal sick people by verbal commands for healing to prevail: for example, the paralytic (Mt 9:2) and the two blind men (Mt 9:27-30). We also read that ' $a]$ blind man came to Jesus beseeching him to heal him' (Mk 8:22). Jesus also understood very well what was common in terms of health matters during his life time because he acknowledged that ' $[t]$ hey that are whole need not a physician, but they that are sick' (Mt 9:12), and that '[ $p$ ]hysician, heal thyself' (Lk 4:23). Individuals who were demon-possessed also received their healing. For example, in Luke 8:36 we read that ' $[t]$ hose who had seen it, told the people how the demon-possessed man had been cured'. Although evidence of his curing sick people is not apparent in the biblical text, Luke was also a medical doctor whom Paul describes as a 'beloved physician' (Col 4:14). It is also possible that Luke the physician attended to Paul's health problems, such as:

[T]here was given to me a thorn in the flesh, the messenger of Satan to buffet me, lest I would be exalted above measure. For this thing I besought the Lord thrice, that it might depart from me. (2 Cor 12:7-8)

Sometimes Jesus would use a ritual to heal his patients, for example, in his healing of the man born blind, Jesus 'spat on the ground, and made clay of the spittle, and he anointed the eyes of the blind man with the clay' (Jn 9:6). He then commanded the blind man to go and wash in the pool of Siloam and the man came back seeing (Jn 9:7).

The above examples demonstrate that during ancient biblical times there were various ways of dealing with ailments. Buthelezi (2011:70) opines that ' $[t]$ o Israel the restoration to health was salvation from all types of sickness'. Thus, salvation is about 'finding protection from the threats of witchcraft and healing from sickness' (Buthelezi 2011:75). Buthelezi (2011:18) further states that 'Christ went around 
preaching the Gospel, healing the sick, feeding the hungry, and setting free those who were demon-possessed'. Buthelezi (2011) has pointed out that:

Church members find themselves in a dilemma of relating with Christian dogma when threatened by sickness, death, misfortunes and a cataphony of tragedies. The members are inclined to resort to ancestral spirits for answers to their plight. (p. 4)

Hence, Buthelezi (2011:44) remarked that '[t]he whole ministry was about recovery, restoration and deliverance from all forms of sickness and demonic bondage'. Nonetheless, Wilkinson (1998:22) was right to state that ' $[t]$ he significant point is that both shalom and hugies coincide in expressing the idea of soundness or wholeness of a person's being which the essence of health is'.

\section{The missionary church and African cultural practices}

This study now delves into discussing health and healing from a postcolonial perspective. Frankenberg and Mani (1993:301, cited in Rugwiji 2013:99) define 'postcolonial' as different ways of staging the encounters between the colonising societies and their other, 'though not always in the same way or to the same degree'. Hadjor (1992:150-152) describes postcolonial formation as a state thought to be at least institutionally free of foreign control, and one now possessing a greater measure of political autonomy than it did under colonialism. When Fanon (1991:230) maintains that 'I am not the slave of the slavery that dehumanized my ancestors', he was not unaware of the trajectories surrounding postcolonial mordancy which not only disfranchised Africans but also dehumanised them as a second category of human species. Thus, my personal experience during colonial times ${ }^{6}$ tends to agree with Fanon's statement by further arguing that during colonialism an African was remembered for a rise only for convenience sake or as an afterthought in order to present a superficial characterisation of fairness.

It is essential to discuss culture in ancient near east (ANE) in relation to the patriarchal tradition. The family of the Hebrew patriarchs (Abraham, Isaac and Jacob) is depicted in the Bible as having had its chief seat in the northern Mesopotamian town of Harran (mid-2nd millennium BCE) belonging to the Hurrian kingdom of Mitanni. The Hebrew people were seminomadic herdsmen and occasionally farmers, ranging close to towns and living in houses as well as tents (see Gn 37:12-17; Ex 12:32, 38; Nm 11:22; 20:4, 8, 11; see also Novacek 2011:66). According to Genesis 12:1-9, God instructs Abram to '[l]eave your country, your people and your father's household and go to a country I will show you'. To Abraham, this moving towards a promise was a step of faith in Yahweh. From there Abraham migrated to the Canaan region (comprising

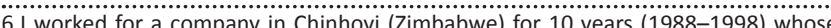
management was predominatly white I was the highly educated employee in the management was predominan white company, yet the lowly paid one. White people were hired for managerial (senior) positions, while I only received the title of a 'senior buyer', without a significan remuneration. When the once colonised people raise postcolonial questions, reference is made to such practices. roughly the region of modern Israel and Lebanon) throughout the vortex of west Asian, Egyptian and east Mediterranean ethno-culture. If the story of Abraham's nomadic itinerary is anything to go by and that the forebears of the Hebrews once lived in the land of Canaan and even possessed the land (Long 1997:25), it follows then that the patriarchs might have borrowed lifestyles or religious tenets from cultures of the people whose land they occupied because Canaan was not an empty land (Ex 13:5).

Having given the above background of the Hebrews and the sojourning of the patriarchs, one is almost convinced that when one gets into contact with a culture outside his or her own, one is likely to be influenced by that culture. One example of the influence of culture is the learning and adoption of a foreign language such as English (from England) because imperialism was established through both the church and the English department of schools (Ngugi 1986:9-18). Language can affect both the mind and culture of an individual (Rugwiji 2008:99). It is the imposition of the foreign literature on a colonised nation to convert it to the culture of imperial powers, and that is assimilation or colonisation of the mind (Achebe 1989:1-20). Perhaps Klímová (2007) was right when she critiqued English as 'a language of oppression'. (p. 8)

During the colonial period, the missionary churches misrepresented local communities they were trying to preach to in a number of ways. One such way is the culture debate and African cultural practices. For example, the question of polygamy among the local people in Rhodesia was problematic (see Zvobgo 1986:44). Hence, Machoko (2013:6) reaffirmed that polygamy - which was part of Zimbabwean culture - was condemned by the missionaries. However, polygamy was not condemned in the Bible, for a king like Solomon was a polygamist (1 Ki 11:3). Reading the Bible in a postcolonial context, the leadership of the Johanne Masowe Apostolic Church (JMAC) has vehemently reacted to the perception that the Bible was written 2000 years ago in a Palestinian culture which was different from the Zimbabwean culture (Machoko 2013:7). Machoko further stated that the Bible addressed Palestinian existential problems which were different from Zimbabwean problems. Hence, it is irrelevant to the needs of contemporary Zimbabwe.

During colonialism in Rhodesia, Africans, African cultures and belief systems were considered primitive. Kato (1975:23) reaffirms the above view when he defines the term 'primitive' as deriving from the Latin word primus, which means 'first', which can further be segmented to mean 'elemental' or 'natural', or 'relating to a relatively simple people or culture', 'self-taught', or 'unschooled'. These are but derogatory and insulting terms formulated and used by people who assumed unquestioned superiority and authority. The assertion that the Bible is so close to the African peoples because of the many items in common between their cultural life and the cultural life of the Jewish people as observed by Mbiti (1970:220) contradicts the missionary church's stance against 
African belief systems. Dickson (1975), who supports the notion of the universality of Yahweh, also maintains that:

We believe that the Yahweh and Father of our Lord Jesus Christ, Creator of Heaven and Earth, Lord of history, has been dealing with humankind at all times and in all parts of the world. It is with this conviction that we study the rich heritage of our African peoples, and have evidence that they know of Him and worship Him. (p. 13)

In concurrence with Dickson, Stephanson (1995) is also right when he observes that:

The colonizers talk of themselves as exceptionally chosen beings, while they also construct tales of derogation against their targeted victims, human beings who deserve to be invaded, dispossessed, subjugated, and annihilated if need be. (pp. 6-7)

Stephanson's (1995) opinion clearly explains how naïve the missionary church was towards African cultures, including the ritual of renaming those who joined the church. African names were also discouraged once an individual joined the church, at mission school or in the village. African names were considered pagan (Rugwiji 2008:101). Dropping their African name was seen as a sign that one had abandoned his or her heathenism and savagery. The so-called Christian names such as Amos, Benedict, Caleb, David and Jacob replaced the Shona names like Muchada, Rangarirai, Mandida, Rumbidzai, Tonderai and Tsungi, to name but a few (Rugwiji 2008:101). When one becomes ill, the church tends to interpret such illness to the demon attached to the cultural or ancestral name. The healing process would therefore begin by dropping the cultural or ancestral name, following by casting out the demon. This explains why Shona naming practices were deeply affected by the coming of Christianity, colonialism and education (Chitando 2001:146). Chitando's (2001) observation is in solidarity with Phillips' (1993:26) assertion which states that the moment of imperialism is also the moment of education, as education was the central strategy of colonising in modern imperialism.

One cannot understand fully what goes on in a particular cultural context unless one is part of that cultural practice. Barton (2003) admits that:

We cannot explain the presuppositions of another culture to ourselves without some translation into terms and categories which did not have exact linguistic equivalents in the culture in question. (p. 141)

For example, in a Shona African culture, the name of a person bears some attachment to the family's lifestyle or tribal history. To replace that person's name is to detach them from the other family members in the larger cultural or traditional set-up. When Chitando (2001:144) states that 'in most societies across the world, considerable care is taken in naming a newly born child', he is assertive of an African culture in which the name of a child has a deeper meaning because 'religious and cultural concerns feature prominently in the selection of names; personal names serve, in fact, to preserve religious and social identity' (Chitando 2001:144).
Some have advanced the opinion that there was a need for Africa to be colonised; otherwise civilisation would not have been established as we have it in modern-day Africa. Blaut's (1993) opinion seems to develop this idea. Blaut (1993:1-43) says that those who control distant and inhabited lands should be well-deserving above their victims. It is in the same vein that when David Livingston described this sub-Saharan African region as a 'dark continent' (Rugwiji 2008:86), he might have referred to both its people who are dark-skinned and also that the inhabitants were ignorant in terms of modern civilisation. It also emerged that economic exploits and gains resulting from colonisation of Africa have been used for the construction and building of empires overseas. Although it is generally viewed that the church is apolitical and that its role is confined to the pulpit, numerous other voices have argued that the sacred institution was associated with colonisation of Africa in general, and Zimbabwe in particular. The Rhodesia Catholic Bishops Conference (RCBC) (now Zimbabwe Catholic Bishops Conference [ZCBC]) has advanced its opinion by confirming that when we speak of the church's mission to permeate and elevate society, there is no question of entering into the field of politics (RCBC 1970:1). The argument becomes more concrete when research by various critical scholars also shows that political and social factors in Europe, and importantly the economic factor, were the basic motivating force for imperialism on the part of most of those who colonised Africa (Abraham 1982:10; Blaut 1993; Ngugi 1986). The following section examines faith, ritual and healing in the church.

\section{African traditional medicine and the position of the church}

Although the lack of Africanisation in the leadership of missionary churches is believed by some to have provided fertile ground for the formation of African Initiated Churches (AICs) (cf. Machoko 2013:3), African Indigenous Churches (AICs) or African Instituted Churches (AICs) - as they are sometimes called - do not necessarily and openly practise African traditional religion as what Machoko and others would want to portray. Poverty-stricken conditions remain major causes that destabilise good health. These include hunger, lack of food or lack of quality food, poor health, inadequate medical care, brain damages as a result of lack of proteinous food for babies, illiteracy, poor living condition, lack of housing or lack of good housing and so on (Ashate 2000:18).

Because of the collapse of the health delivery system in Zimbabwe, the escalation of complications and the increase in incurable illnesses such as HIV and AIDS and cancer, people suffering from various illnesses have opted to visit traditional healers. Christians who cannot get assistance either from modern and traditional health establishments or from 'miracle healing' of the church also nicodimously'

7 The term is used to denote 'sneaking out', making sure that one is not seen by e........ the pastor or anyone from the [traditor or any ] during the night or far away from their places of residence to [traditional healer] during the night or far away from their places of residence to avoid being spotted. They do so in order to evade some castigation because they may still want to belong to a particular church for fellowship and worship services. 
seek the services of a traditional healer. It is therefore ostensible that because of persistence of illness, Christians also go to consult the traditional healer (Mafico 1986:400-409). Admittedly, Temba Mafico sees the majority of African Christians as protesting against the missionary church's failure to deal with their spiritual, social or family problems as reasons for their deviation. However, this 'protest' is not openly expressed by African Christians as a legitimate basis for consulting the traditional healer. This clandestine behaviour by Christians is motivated by the teaching of the church, which prohibits its adherents - the bulk of whom are black Africans - to use African herbs in curing health complications. African traditional herbs and the African way of dealing with ailments are perceived as evil and satanic (Rugwiji 2008:102). The myth of regarding ATM as evil and satanic is in direct contrast with the finding that traditional medicine before colonial rule at the end of 19th century was a very prestigious enterprise (Chavunduka 1994:1). Not only were traditional healers regarded as the only medical specialists, but they were expected to deal with a wide range of social problems as well.

Although the role of a traditional healer is ridiculed and regarded by some as primitive, Chavunduka (1994:1) beckons that ' $[i] n$ addition to being a medical practitioner, the traditional healer was a religious consultant, a legal and political advisor, a marriage counsellor, a police detective and a social worker'. It is not unusual that African cultural belief systems have not been given a fair treatment by the missionary church. Rugwiji (2008:102) shared the disillusionment of many culturally entrenched Africans that Western medicine, introduced by colonial governments and missionaries, witnessed the discouragement and denigration of traditional medicine as an effective way of curing many forms of African illnesses.

Traditional healers were perceived as 'rogues and deceivers' in a context where modern medicine chests brought by missionaries, primarily for their own use, could not be accessed by the majority of Zimbabweans, as Chavunduka (1994:5) posits. The later centuries witnessed some amount of tolerance in the trend of Western perception about African cultures. African peoples, their cultures and religions, began to be regarded by missionaries and anthropologists as primitive, heathen and pagan (see Rugwiji 2008:102).

\section{Pentecostalism and faith-based healing in Zimbabwe}

Togarasei (2016:1) could not have said it better to affirm that ' $[t]$ he current picture of Zimbabwean Christianity is heavily influenced by Pentecostalism in mainline churches, African Initiated Churches (AICs) and the various Pentecostal movements'. Despite the impact of political turbulence and alleged human rights crises in Zimbabwe (see Davidson \& Purohit 2004:108-131; Rugwiji 2012), there is freedom of worship in the Southern African country which comprises the so-called mainline churches, Islam ${ }^{8}$, Pentecostal, Apostolic and AICs. Almost all apostolic religious communities (ARCs) or AICs are Pentecostal movements (PMs) and charismatic in character (Maxwell 2006).

Gundani (2001:135) has opined that African Christianity is witnessing an unprecedented interest in healing, especially since the first quarter of the 20th century, with the emergence of Zionist and Apostolic churches. This unprecedented interest in healing as Gundani puts it has influenced the rise in numbers of faith healing practitioners as well as AICs and PMs. The Holy Spirit (Mweya) plays a central role in the spiritual life, beliefs and faith healing of the ARC (Maguranyanga 2011:vii). African Initiated Churches believe in prophets, faith healing, speaking in tongues, cults of personalities, importance of charismatic leadership and praying for their members to get jobs in government and the private sector, and these have led many Zimbabweans to convert to AICs (Machoko 2013:1).

Mweya is believed to foretell and forewarn about any impending disease outbreak, tragedy, complications as well as how to treat illnesses (Maguranyanga 2011:vii). Mweya works through prophets and church (spirit-filled) members and endows them with special healing and prophetic powers and gifts (Maguranyanga 2011:vii). Gundani (2001:135) also reiterated that scholars have coined the epithet 'healing churches' to designate those churches where healing in its broadest sense plays a pivotal role, informing doctrine, pastoral practice and the recruitment of members. Oduro (2006), who concurs with both Gundani (2001) and Machoko (2013), also presupposes AICs as:

Congregations and / or denominations planted, led, administered, supported, propagated, motivated, and funded by Africans for the purpose of proclaiming the Gospel of Jesus Christ and worshipping the Triune God in the context and worldview of Africa and Africans. (p. 2)

It appears AICs were all established by African initiatives rather than by foreign missionary agenda (Oduro 2006:1; see also Machoko 2013:1). Examples of AICs include, but not limited to, JMAC, Johanne Marange Pentecostal Church (JMPC), Johane Masowe Chishanu Apostolic Church (JMCAC), Zion Christian Church (ZCC) and Africa Apostolic Church (AAC), to name but a few. Various sources support the view that AICs emerged as a protest against the missionary church's stance both in belief and in practice (Machoko 2013:6).

Concrete reasons for the emergence of AICs are divergent. For example, JMAC saw white missionaries as insincere. Johanne Masowe Apostolic Church attested that white people and their book were not trustworthy, for missionaries said one thing, while the Bible said another (Angelke 2007:5). The other reason is the alleged failure by the missionary church to provide therapeutic solutions to ailments affecting 8.The present study has deliberately left out the discussion on Islam and other nonChristian faiths for a future project. 
congregants. Johanne Marange Pentecostal Church members generally believe that prophecy, faith and prayer will heal illness. Also, it is reported that members of JMAC are discouraged to use Western medication but to rely on faith healing (Musoni 2013:78). Although it has been noted that most AICs have deviated over the years from their original agenda to a focus on the gospel of prosperity, JMCAC is one such AIC that has remained faithful to its original agenda (Dodo, Banda \& Dodo 2014:1-2).

African Initiated Churches' agenda largely comprises faith healing as opposed to other modernised and evangelistic ministries whose main thrust is to attract 'those who are seeking both success and prosperity in life' (Togarasei 2005:355). Examples of prosperity churches include Zimbabwe Assemblies of God Africa (ZAOGA), Family of God (FOG) and Hear the Word Ministries (HWM) (Togarasei 2005:355), among numerous others. In most cases, prosperity churches are dominated by the affluent and those smartly dressed. Those seeking wealth and success find their way into prosperity church doctrines. Although healing is part of worship in ZAOGA, FOG and/or HWM, sermons and teaching on prosperity, giving and tithing are prioritised. African Initiated Churches are non-evangelistic. However, they are more into prophetism and healing.

Among visitors with health complications seeking assistance from AICs - both believers from other denominations and non-believers - most of them would be seeking prophetic annunciation and healing. Most of the people who visit these 'prophets' at AICs have what I call hermeneutics of assumptions which they want the faith healer to confirm. The process of healing begins with prophetic utterances which are usually commensurate with some idea about what the consultee already has. However, others have special needs such as wealth and well-being as well as job opportunities. Dodo et al. (2014:9) have reiterated that poverty is generally believed and known to be one of the causes of unrest in the world. They further noted that eliminating poverty requires employment so that basic needs are met. It is also said that in Zimbabwe, especially following the devastating economic crisis that started in 1999, prospects of securing employment have become very difficult. Dodo et al. (2014:9) have pointed out that JMCAC, through its prophecy, has played a role in helping people secure jobs for decent lives. Besides prophetic and faith healing services, AICs also play other roles, such as counselling and therapy to HIV and AIDS patients, visiting diseased individuals at their home and offering information, prayers and salvation (Burchardt, Hardon \& De Klerk 2009:40). It is further noted that AICs have also begun recommending anti-retroviral treatment (ART) to people living with AIDS (PLWA) when they come for ritual treatment by referring them to clinic.

Generally, members of AICs neither visit a medical doctor nor go to modern healthcare centres when they are sick. Despite the criticism that faith healing and strict adherence to church beliefs and practices undermine modern healthcare-seeking (Maguranyanga 2011:vi), AICs and/or PMs command a very large following in terms of congregants who converge at the designated shrine for faith healing. Most of the complications (e.g. diabetes, loss of sight, loss of blood, cancer, persistent headaches, stomach aches and diarrhoea, paralysis, etc.) that Africans experience are usually believed to be caused by witchcraft, bad omens or curses. Mufunda, Albin and Hjelm (2012:123) have concurred that to a higher extent, the causes of diabetes are attributed to supernatural factors (e.g. punishment from God and witchcraft). It is also affirmed that people with various health complications such as the ones noted above also search for information from self-help groups and help outside the professional health sector (Mufunda et al. 2012:123).

Even in instances where serious need is real and modern medical assistance may be needed, some AICs, ARCs and PMs still emphasise faith and adherence to church doctrine and practices (Maguranyanga 2011:6). However, claims by AICs, ARCs and PMs for faith healing have been widely criticised by experts within the modern and formal healthcare establishments who argue for modern medical methods of curing illnesses. Early diagnosis of ailment, prevention through immunisation and / or treatment and other healthcare offerings are recommended. These healthcare services can only be administered at conventional and organised medical facilities. Albeit efforts by the Zimbabwean Ministry of Health and Child Care towards combating vaccinepreventable diseases, such as polio, through immunisation (Maguranyanga 2011:vii), AICs, ARCs and PMs have neither been cooperating nor reciprocating by presenting babies or children for clinical attention. In my view, freedom of worship in Zimbabwe does not imply neglecting the essential services earmarked for prevention against humanitarian crises, such as cholera and various other waterborne diseases.

\section{Conclusions}

This article has explored that health and healing were central in the Bible. It was shown that prophets and priests (and Jesus himself) performed rituals to heal the sick. It was argued that before the emergence of the missionary church in Zimbabwe, culturally entrenched Africans were accustomed to consult the traditional healer in order to soothe ailments. The article showed that although few people still visit African traditional healers for health and/or other social solutions, others have switched to faith healing practitioners, such as prophets from AICs.

It does not appear as though AICs such as JMAC, JMPC, JMCAC, ZCC and AAC, among others, are responding positively to utilise conventional methods of healthcare such as those offered by modern clinics, hospitals and/or other professional medical practitioners. In the final analysis, one would therefore conclude that the continuous ceremonial visits by individuals for faith healing at decentralised centres of worship by AICs where they are not coerced serve to confirm in a way that people with health complications and/ or other social needs are getting assistance. If that is not the case, then Karl Marx' assertion is practical when he noted 
that ' $r$ ]eligion is the opium of the people' (Cox 1992:4). In my view, it is not feasible for people to continue visiting either a traditional healer for ATM or AICs for FBH when services offered are not meeting the demands of their health complications.

\section{Acknowledgements Competing interests}

The author has declared that no competing interests exist.

\section{Authors' contribution}

I declare that I am the sole author of this research article.

\section{Ethical consideration}

This article followed all ethical standards for a research without direct contact with human or animal subjects.

\section{Funding information}

This research received no specific grant from any funding agency in the public, commercial or not-for-profit sectors.

\section{Data availability statement}

Data sharing is not applicable to this article as no new data were created or analysed in this study.

\section{Disclaimer}

The views and opinions expressed in this article are those of the author and do not necessarily reflect the official policy or position of any affiliated agency of the author.

\section{References}

Abraham, K., 1982, From race to class, Grassroots, London.

Achebe, C., 1989, Hopes and impediments: Selected essays, Doubleday, New York.

Allen, R.B., 1996, 'The "bloody bridegroom" in Exodus 4:24-26', Bibliotheca Sacra 153, 259-269

Angelke, M.E., 2007, A problem of presence: Beyond Scripture in an African church, University of California Press, Berkeley, CA.

Ashate, E., 2000, 'Root causes of poverty and displacement in West Africa: A theological reflection', in E. Martey \& M.G. Nwagwu (eds.), The Gospel, poverty and the displaced in Africa, pp. 18-21, Presbyterian Press, Ghana.

Ashcroft, B., Griffiths, G. \& Tiffin, H., 2000, Postcolonial studies: The key concepts, 2nd edn., Routledge, London.

Banana, S.C., 1991, Come and share: Introduction to Christian theology, Mambo Press, Gweru.

Barton, J., 2003, Understanding Old Testament ethics: Approaches and explorations, Westminster John Knox Press, London, Louisville, KY.

Bhabha, H.K., 1994, The location of culture, Routledge, New York.

Bhebe, N., 1979, Christianity and traditional religion in western Zimbabwe, 1859-1923, Longman Group Ltd., London.

Blaut, J.M., 1993, The Colonizer's model of the world: Geographical diffusionism and Eurocentric history, Guilford Press, New York.

Bodibe, C. \& Sodi, T., 1997, 'Indigenous healing', in Health policy issues for South Africa pp. 181-192, MASA Multimedia Publications, Cape Town.

Burchardt, M., Hardon, A. \& De Klerk, J., 2009, Faith matters: Religion and biomedical treatment for HIV/Aids in sub-Sahara Africa, AMB Publishers, Diemen.

Buthelezi, T.S., 2011, 'A critical analysis of the doctrine of salvation in Free Evangelical Assemblies in Swaziland: A contextual theology', Master's dissertation, South Africa Theological Seminary.

Castle, G., 2001, 'Glossary', in G. Castle (ed.), Postcolonial discourses: An anthology, pp. 502-510, Blackwell, Malden, MA.
Chavunduka, G.L., 1994, Traditional medicine in modern Zimbabwe, UZ Publications, Harare.

Chitando, E., 2001, 'Signs and portents? Theophoric names in Zimbabwe', Word \& World XX1(2), 144-151.

Cox, J.L., 2014, The invention of God in indigenous societies, Acumen, Durham https://doi.org/10.4324/9781315729473

Cox, L.J., 1992, Expressing the sacred: An introduction to phenomenology of religion, UZ Publications, Harare.

Davidson, L. \& Purohit, R., 2004, 'The Zimbabwean human rights crisis: A collaborative approach to international advocacy', Yale Human Rights and Development Journal 7(1), 108-131.

Dickson, K., 1975, 'African theology: Origin, methodology and content', Journal of Religious Thought 32, 13.

Dodo, O., Banda, G.R. \& Dodo, G., 2014, 'African initiated churches, pivotal in peacebuilding: A case of the Johane Masowe Chishanu', Journal of Religion \& Society $16,1-12$.

Dondolo, L., 2005, 'Intangible heritage: The production of indigenous knowledge in various aspects of social Life', Indilinga: African Journal of Indigenous Knowledge Systems 4(6), 110-126.

Fanon, F., 1991, Black skin, white masks, Pluto Press, London.

Frankenberg, R. \& Mani, L., 1993, “Crosscurrents, crosstalk: Race, "postcoloniality" and politics of location', Cultural Studies 7(2), 292-310. https://doi.org/10.1080/ 09502389300490181

Freeman, D.L. \& Abrams, R.J.Z., 1999, Illness and health in the Jewish Tradition Writings from the Bible Today, The Jewish Publication Society, Philadelphia, PA.

Gundani, P., 2001, 'Church, media and healing: A case study from Zimbabwe', Word \& World XXI(2), 135-143.

Hadjor, K.B., 1992, The Penguin Dictionary of third world terms, Penguin, London.

Hall, S., 1996, 'When was the postcolonial? Thinking at that limit', in I. Chambers \& L. Curti (eds.), The postcolonial question: Common skies, divided horizons, pp. 242-260, Routledge, New York.

Hasel, G.F., 1983, 'Healing in the Old Testament', Andrews University Seminary Studies 21(3), 191-202.

Holderness, H., 1985, 'Lost chance: Southern Rhodesia (1945-1958)', Zimbabwe Publishing House, Harare.

Kato, L.B., 1975, Theological pitfalls in Africa, Evangel, Kisumu.

Klímová, Z., 2007, 'English as a language of oppression', BA thesis, Faculty of Arts, Masaryk University.

Klopper, F., 1992, 'We have a right to believe differently: 2 Kings 5:1-27 and religious tolerance', in W. Wessels \& E.H. Scheffler (eds.), Old Testament science and reality: A mosaic for deist, pp. 188-207, Verba Vitae, Pretoria.

Kwok, P.L., 1995, Discovering the Bible in the non-biblical world, Orbis, New York.

Long, E.L.R., 1997, To liberate and redeem - Moral reflections on the biblical narrative, The Pilgrim Press, Cleveland, $\mathrm{OH}$

Machoko, C.G., 2013, 'African initiated churches and party politics: Zimbabwean experience', The International Journal of African Catholicism 4(1), 1-40.

Mafico, L.J.T., 1986, 'The Old Testament and effective evangelism in Africa', International Review of Mission 75, 400-409. https://doi.org/10.1111/j.1758-6631.1986. tb01494.x

Maguranyanga, B., 2011, Apostolic religion, health and utilization of maternal and child health services in Zimbabwe, Collaborative Centre for Operational Research and Evaluation, Unicef, Harare.

Makunike, E.C., 1998, I won't call you Sir!, Southern Africa Political Economic Series, Harare.

Maxwell, D., 2006, African gifts of the spirit: Pentecostalism and the rise of Zimbabwean transnational religious movement, Ohio University Press, Athens.

Mbiti, J., 1970, Concepts of God in Africa, Society for Promoting Christian Knowledge, London.

Mishra, V. \& Hodges, B., 1994, 'What is post-colonialism?', in P. William \& L. Chrisman (eds.), Colonial discourse and post-colonial theory pp. 285-288, Columbia (eds.), Colonial discourse
University Press, New York.

Mofokeng, T., 1988, 'Black Christians, the Bible and liberation', Journal of Black Theology 2, 34.

Mudimbe, V.Y., 1977, The idea of African, James Curry, London.

Mufunda, E., Albin, B. \& Hjelm, K., 2012, 'Differences in health and illness beliefs in Zimbabwean men and women with diabetes', Open Nursing Journal 6, 117-125. https://doi.org/10.2174/1874434601206010117

Musoni, P., 2013, 'African Pentecostalism and sustainable development: A study on the Zimbabwe Assemblies of God Africa, Forward in Faith Church', International Journal of Humanities and Social Science Invention 2(10), 75-82.

Ndlovu, S.S.P., 2016, 'Traditional healing in KwaZulu-Natal Province: A study of University students' assessment, perceptions and attitudes', Master's dissertation, University of KwaZulu-Natal, Pietermaritzburg.

Ngugi, W.T., 1986, Decolonising the mind: The politics of language in African literature, James Curry, London.

Novacek, G.V., 2011, Ancient Israel: Highlights from collections of the Oriental Institute of the University of Chicago, University of Chicago Press, Chicago, IL.

Nyambi, O. \& Mangena, T., 2016, 'Introduction', in O. Nyambi, T. Mangena \& C. Pfukwa (eds.), The postcolonial condition of names and naming practices in Southern Africa, pp. 1-19, Cambridge Scholars Publishing, Cambridge. 
Oduro, T., 2006, 'Theological education and training: Challenges of African independent churches in Ghana', Journal of African Instituted Church Theology 2(1), $1-15$

Phillips, J., 1993, 'Educating the savages', in J. White (ed.), Recasting the world: Writing after colonialism, p. 26, John Hopkins University Press, Baltimore, MD.

Ratheiser, M.H.G., 2007, Mitzvoth ethics and the Jewish bible: The end of Old Testament theology, T \& T Clark, London.

RCBC, 1970, 'A crisis of conscience', AFCAST, 17 March, p. 1, viewed 20 August 2019, from http://www.afcast.org.zw/zimbabwe/ZimPL1970.htm

Rugwiji, T., 2013, 'Appropriating Judean postexilic literature in a postcolonial discourse: A case for Zimbabwe', PhD thesis, University of South Africa, Pretoria.

Rugwiji, T., 2012, Rereading the exodus liberation motif in the modern post-biblical world: The Zimbabwean society and the reality of oppression, LAP Academic Publishing, Saarbrūcken.

Rugwiji, T., 2008, 'Reading the exodus tradition from a Zimbabwean perspective', MA dissertation, University of South Africa, Pretoria.

Rukundwa, L.S. \& Van Aarde, A., 2007, 'The formation of postcolonial theory' HTS Teologiese Studies/Theological Studies 63(3), 1171-1194. https://doi.org/ 10.4102/hts.v63i3.237

Said, E., 1993, Culture and imperialism, Vintage, New York.

Snyman, G.F., 2002, 'The body, rhetoric and postcolonial criticism', Religion and Theology 9(1 and 2), 63-88. https://doi.org/10.1163/157430102X00043
Spivak, G.C., 1988, In other worlds: Essays in cultural politics, Routledge, New York.

Spronk, K., 2004, 'Good death and bad death in ancient Israel according to biblical lore', Social Science \& Medicine 58, 987-995. https://doi.org/10.1016/j. socscimed.2003.10.035

Stephanson, A., 1995, Manifest destiny: American expansion and the empire of right, Hill and Wang, New York.

Sugirtharajah, R.S., 2002, Postcolonial criticism and biblical interpretation, Oxford University Press, Oxford.

Swindoll, C.R., 1988, Living beyond the daily grind, Book II, Word Publishing, Dallas, TX.

Togarasei, L., 2005, 'Pentecostalism as an urban phenomenon: The case of the Family of God Church in Zimbabwe', Exchange 34(4), 349-375. https://doi. org/10.1163/157254305774851484

Togarasei, L., 2016, 'Historicising Pentecostal Christianity in Zimbabwe', Studia Historiae Ecclesiasticae 42(2), 1-13. https://doi.org/10.25159/2412-4265/103

West, G.O., 1997, 'Finding a place among the posts for postcolonial criticism in biblical studies in South Africa', Old Testament Essays 10(2), 322-342.

Wilkinson, J., 1998, The Bible and healing. A medical and theological commentary, The Handsel Press, Edinburgh.

Young, R.J.C., 2001, Postcolonialism: An historical introduction, Blackwell, London.

Zvobgo, C.J., 1986, 'Aspects of interaction between Christianity and African culture in colonial Zimbabwe, 1893-1934', Zambezia XIII(i), 43-57. 